\title{
Analysis of Discourse Structure in Higher Education Hymns (Studies at State Universities in East Java)
}

\author{
Parto $^{1}$, Yulianto Bambang ${ }^{2}$, Kisyani ${ }^{3}$ \\ ${ }_{1,2,3}$ Universitas Negeri Surabaya, Indonesia \\ parto.fkip@unej.ac.id
}

\section{Abstract}

The purpose of this research is to describe and find the discourse structure of college hymns through macro structure, superstructure, and micro structure. This research was conducted using a qualitative descriptive approach. Source of hymn data for seven state universities in East Java. The selection of seven state universities in East Java was based on the reason that the ways in which higher education hymns were created were similar so that the results of this study could become a reference in the meaning of university hymns in general. Based on the results of data analysis, it can be concluded that (1) the hymn of state universities in East Java has similarities in its macro structure, namely the theme of praise or worship, (2) the superstructure or schematic structure of the hymn in public universities in East Java begins with the naming or title of the hymn which is similar, namely beginning with the word hymn and followed by the name of the institution; In general, the form of a hymn is made in stanzas like a song or poetry (3) semantically a college hymn generally leads the audience to an opinion that the university is praiseworthy and proud, (4) based on the cohesion of the hymn of state universities in East Java generally the hymn descriptions are related to the title, either the overall description or the description of the sections or the comparisons, even each line in the hymn of public universities in East Java refers to or is directed at the institution whose name is mentioned in the title; active and passive sentences, (5) diction in the hymn text of state universities in East Java, like songs in general, are very concerned with the harmony of the sound of language or emphasizing rhyme and poetry, especially diction at the end of the line (6) hymns of public universities in East Java tends to use simple language, but from the analysis results it is found that several styles of language.
Keywords

hymn; discourse

structural analysis;

macro structure;

superstructure; micro structure

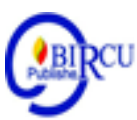

\section{Introduction}

Hymn is a series of lyrics and songs that serve as a medium for introducing the advantages and characteristics of an organization or agency. Through hymns, organizations or agencies explain the identities that their members are proud of. As one proof of the pride of the members of the hymn, the hymn is always sung during ceremonial events. The ownership of the hymn in an organization or agency seems to have become a culture. That is, it is not yet complete if an agency does not have a hymn. This condition is in accordance with the statement that language reflects the culture (habits, views, religions, etc.) of its speakers (Bustomi, 2019). In this study, the hymn studied was the hymn of public universities in East Java. 
Language research in song texts can be directed at the songwriter's ability to use language to achieve communication effectiveness. According to Basirizadeh (2020) Theory in general tends to see our external world as socially and linguistically constructed, as "always already" textualised discourse but ecocriticism calls this long standing theoretical orthodoxy into question. Ecocriticism claims that there is nature everywhere inside or outside of literature. Darwis (2020) stated that language plays an important role in human life. Humans use language as a means to communicate. Language is related to the principle of politeness of language which is mentioned the maxims of wisdom, generosity, appreciation, simplicity, consensus and conclusions. So from the six maxims the adolescent must use a lot of maxims which expedite the conversation, cooperate with each other in speaking and give mutual appreciation in speaking and at least the simplicity maxim is needed.

Language research in song texts also focuses on the language symbol system that appears in communication which includes (1) the characteristics of the relationship between form, symbol and meaning; (2) the relationship between the linguistic form and the outside world that it refers to; and (3) the relationship between symbols and their use (Aminuddin, 1987: 40). Thus, language research in song texts is not limited to the text alone, but looks at its relationship with the things that surround it. In the context of this research, the song text in the Higher Education Hymn also reflects the three symbol systems. The meaning contained in the college hymn discourse can vary, it can be related to history, vision-mission, ideology, motivation, or perhaps the character that you want to develop, all of which are deliberately exhaled to elevate the greatness of the university.

The meanings contained in the text / discourse of the college hymn need to be understood by each academic community so that a sense of belonging or feeling is part of the university. The feeling of belonging or feeling part of a university if the academicians have it, it will stick even though they are no longer in the college campus environment. It can be felt when one time listening to the hymn of his alma mater again.

Language research in song texts also focuses on the language symbol system that appears in communication which includes (1) the characteristics of the relationship between form, symbol and meaning; (2) the relationship between the linguistic form and the outside world that it refers to; and (3) the relationship between symbols and their use (Aminuddin, 1987: 40). Thus, language research in the song text is not limited to the text alone but looks at its relationship with the things that surround it. In the context of this research, the song text in the Higher Education Hymn also reflects the three symbol systems.

In particular, the hymns in this study were examined through the study of discourse structure. This study uses a discourse structure analysis study developed by Van Dijk in understanding hymns. The structure analysis of Van Dijk's discourse has three areas of study, namely macro structure, superstructure and microstructure.

Van Dijk sees a discourse from several structures or levels, each of which supports each other. He divided it into three levels. First, the macro structure. This structure is the global or general meaning of an observable text. Second, superstructure, this is a discourse structure that is related to the framework of a text, namely how a text is structured into a whole discourse. The third is micro structure, which is related to meaning, sentence arrangement, use of language style, and rhetoric. In a discourse, the three structures cannot be separated. In order to obtain a complete meaning and understanding of the text or discourse, it is necessary to examine all three. Therefore, the focus of this research is trying to uncover three structures in the hymn of public universities. 


\section{Review of Literatures}

\subsection{Discourse Limits}

The term discourse has a fairly broad and complex meaning. This is not only because discourse is a linguistic area, but because it is related to social practice in social interaction. Discourse in KBBI is interpreted as the most complete language unit. The same thing was stated by Kridalaksana (2008: 179) that what we call discourse is the most complete language unit; in the linguistic level discourse is the highest linguistic unit; This discourse is manifested in the form of essays or complete texts such as short stories, articles, books, etc., in which there are paragraphs, sentences or words that carry a complete message.

Discourse can also be interpreted as a series of sentences that relate to one another in a unity of meaning. In that sense, discourse can actually be written or oral. Generally, discourse in the form of writing is recognized as text. However, because discourse which is in the form of oral form if it is studied must be transcribed first into written form, both written and spoken discourse are referred to as text as well. Hawton (in Mills 1997: 4) expresses his opinion that discourse is interpreted as communication with language media which can be seen as a transaction between speaker and listener, as an interpersonal activity whose shape is determined by its social goals.

Meanwhile, from the perspective of reality, discourse is divided into verbal and nonverbal discourses. That is, a discourse can be realized with the exposure of verbal and nonverbal language. Verbal language in discourse appears both in spoken discourse and written discourse, while nonverbal language is only used in spoken discourse. Verbal discourse refers to a series of meaningful language structures while non-verbal discourse refers to a series outside of language, which is a series of meaningful visual symbols (Sudarma, 1994: 8-9).

\subsection{College Hymn}

We find many definitions of hymns in various media, but in essence they have almost the same meaning, namely hymns, sung praises, gita puja, and so on. On the steemit web, it is defined that a hymn is a type songs that contain lyrics devoted to God, great figures or someone who is glorified, such as a hero or teacher. Hymns are also songs intended for a people, organization, alma mater, or institution. Apart from containing the lyrics of praise, hymns are also types of songs that contain lyrics of prayer, gratitude, struggle, hope, or great impressions.

In KBBI, hymns are interpreted as gita puja or songs of praise or worship (for God, homeland, institutions, etc.). The creation of hymns was usually meant to hum a cult of something. Something that is meant can be anything that deserves adoration or praise, it can be praise for God, praise for the homeland (nation), institutions (including educational institutions), etc. Thus, in Indonesia there are many hymn songs created, for example the Teacher's Hymn (as a compliment to the teaching profession), Scout Hymn (as a compliment in the scouting world), Indonesian Hymn (as an expression of gratitude and worship of Almighty God). , etc.

For a university, the hymn is an identity like other identities such as the alma mater's logo and jacket. In a university, the presence of hymns apart from functioning as a medium for conveying higher education goals, is usually also present in campus ceremonial events such as new student inaugurations, graduations, open senate sessions, and others. 


\subsection{Dis course Analysis}

This study is a method or theory that can be applied in research activities regarding the correlation between elements in a discourse. In connection with that, there is an opinion that discourse analysis is a creativity to describe a text whose tendency is to achieve certain goals (Darma, 2013: 49). Thus, the analysis carried out is influenced by the writer's understanding of various factors. It must also be realized that behind a discourse there is meaning, both implied and explicit.

Another opinion is that discourse analysis is descriptive in nature which sees discourse as a language text (Santoso, 2012: 10-11). This is in line with the opinion of Brown \& Yule (1996: 1), namely that discourse analysis is an analysis of the language used. In this study, the analysis carried out was also an analysis by describing the language text used in the hymns of public universities in East Java

Van Dijk defines a topic as the macro structure of a discourse. From the topic, it can be seen the problems and actions taken by the author in overcoming a problem. Actions, decisions, or opinions can be observed in the macro structure of a discourse. The macro structure (topic) also provides an overview of what will be done to solve a problem. In van Dijk's framework, topics in a text are usually supported by several subtopics. Each of these subtopics supports, strengthens, and even forms the main topic. Therefore, it is not surprising that all elements in the text refer to and support the topics in the text (Eriyanto, 2001).

\section{Research Method}

This type of research is qualitative. Qualitative research emphasizes the inductive assessment process, starting from seeing and studying phenomena, then concluding them. The hymn was studied inductively to find a complete meaning in the college hymn. The data of this research are the hymn lyrics of public universities in East Java. Source of hymn data for seven state universities in East Java. The selection of seven state universities in East Java was based on the following reasons.

1) State tertiary institutions that are the source of research data are tertiary institutions under the ministry of education and culture. This is a limitation in this study.

2) Public universities can be sure to have the hymn set out in the statute. The ways in which higher education hymns are created are similar so that the results of this study can become a reference in the meaning of tertiary hymns in Indonesia in general.

3) State universities that become data sources are state universities in East Java which have different histories and histories that reflect universities in Indonesia. Universities that have changed form are represented by Unesa and UM, universities in the form of universities are represented by Unair, UB, and Unej with their respective histories, colleges in the form of institutes are represented by ITS, the new universities are represented by UTM. On this basis, then the seven hymns of state universities in East Java were considered representative.

4) Not all private colleges have a college hymn. Therefore, private universities are not the source of research data.

5) The state universities that are taken are universities that focus on academic education, not vocational education.

On this basis, the data source of this research is the hymn of the universities of Surabaya State University (Unesa), Ten November Institute (ITS), Airlangga University (Unair), Malang State University (UM), Brawijaya University (UB), Jember University (Unej ), and Trunojoyo Madura University (UTM). 
The key instrument of this research is the researcher. Researchers are a key instrument which is the hallmark of qualitative research. This is based on the full involvement of the researcher in all research activities. The researcher sets focus. Researchers play a full role in data collection, starting from the reading process, marking, classification. In addition, researchers also play a full role in reducing data, interpreting data, and concluding research results. In this study, data collection using documentation techniques. Documentation is done by tracing hymn data from seven state universities in East Java. The hymn data was obtained through google search with keywords according to the data and data sources of this study. The procedure in documentation technique is as follows:

1) reading hymns;

2) marking text in hymns containing discourse structures including macro, superstructure and micro structures; and

3) reduce new data

\section{Results and Discussion}

\subsection{Hymn is a Series of Texts of University Pride and Identity}

Hymn is a song that is usually sung in ceremonial events in universities. For that, it can be said that the hymn is a form of university pride. As a discourse text, of course a hymn has a structure that builds an expression of pride through the verses that are outlined in the hymn verses. Broadly speaking, the hymn structure consists of three parts, namely prayer, hope, and lines of encouragement. The three structures are interrelated and have a meaningful melodic character.

There must be a prayer phrase in every hymn, the prayer is inserted as a form of request to God Almighty for the glory of the name of the college. In addition, expressions of hope must also exist in the hymn song as a form of good wishes that are expected for the future of the university, along with the achievement of the goals the university wants to achieve through its vision and mission. The final hymn structure is composed of arrays full of enthusiasm, with the intention of gratitude and motivation to continue to achieve common goals.

If the college hymn does not reflect pride and identity, it does not fulfill its function well. The text in the hymn that does not reflect pride will be the text of the song not glorified by the institution. As an illustration, the UTM hymn does not write words that refer to UTM, so the song is not part of UTM's identity. Therefore, all hymns invariably rewrite the name of the institution either in full or in acronym. Based on the above description, the main characteristic of the hymn is the textual writing of the university's identity and nationality in the text. This will be the basis and characteristic that the hymn is the nationality and identity of the college.

\subsection{Hymns Are Replicas of Higher Education's Vision and Mission}

A whole structure is built by the components that are interwoven in a discourse organization (Mulyana, 2005: 25). For this reason, apart from having a structure consisting of interrelated elements, hymns are also formed from the superstructures that build them. According to Shinta (2016: 3), the superstructure shows how the parts in discourse are arranged and ordered to form a unity of meaning. It can also be said that the superstructure is the framework of a text, such as the introduction, content, closure, and conclusion (Eriyanto, 2006: 227). 
Judging from its function, the hymn sung in ceremonial activities becomes a medium to ground the university's vision and mission. This will be a fun medium and means to introduce the university's vision and mission properly and beautifully. For this reason, every institution that will compose a characteristic song requires an interpretation of the long text written in the institution's vision and mission. This will become a symbol of identity, that the institution's characterizing text is an attempt to perpetuate the vision and mission in the institution's characteristic song text. In this context, the song is called a hymn.

The semantic phenomenon above can be found in the hymn song on the naming aspect of higher education. Generally, in historical records, the names of universities usually include the word "State" to show a label that the university is a public university. However, there are still a number of state universities that do not carry the label "State" even though they are state universities. Examples are the November 10 Institute of Technology (ITS), Brawijaya University, (UB), and Jember University (Unej).

Historically, two universities, namely the State University of Surabaya and the State University of Malang, were the IKIP institutions that were turned into universities. The labeling of the word country in the former IKIP shows its history. There is a change in the shape of the institution.

In contrast to the two examples above, ITS, UB, and Unej are not ex-IKIP. Thus, the tertiary institution does not assign the label "country" to the name of the institution. This shows the different historical records between institutions with the word country and not. On the other hand, the choice of words in the university hymn shows great love for the name of the institution which is written in the hymn text. There are many choices of words that show this love and nationality. In this research, the syntactic study is more focused on the aspects of cohesion, coherence, and sentence form. From the research results, it was found that the hymn of state universities in East Java had very good cohesion. The cohesion of the college hymn is evident from the association between the description of the hymn and its title. So it is with the coherence of the college hymn. Higher education hymns in Indonesia also have good coherence. The coherence of this college hymn can be seen from the links between the lines in each verse and the links between the lines in the hymn. Whereas when viewed from the form of the sentence, college hymns tend to use a long compound sentence form and a variety of active and passive forms.

In addition, the syntax in hymns is related to variations in the form of words which are intended as a medium for recognizing the name of the University. Based on the syntactic aspect, two variations of the hymn form are found, namely using acronyms and also written in full. According to Kridalaksana (2008: 5) acronym is short in the form of a combination of letters or syllables or other parts that are written and pronounced as words that are in accordance with linguistic rules. In other words, an acronym can be said to be a form of word abbreviation that aims to be better known based on other naming variations. The formation of abbreviations or acronyms cannot be made carelessly, but must pay attention to their compatibility with the phonotactic rules of the language in question. Examples of using abbreviations or acronyms in hymns are found in abbreviations for the mention of the campus name, for example in the ITS, UM, and UNESA hymns.

The mention of the name ITS is more often used in hymns than the abbreviation, namely the November 10 Institute of Technology, because the college abbreviation is indeed better known so naming with abbreviations is more commonly used. Likewise, the abbreviation for naming UM is more famous than the original name State University of Malang. As for the UNESA University, it is also easier to be known by the name UNESA than the abbreviation of the State University of Surabaya. Based on these considerations, 
in mentioning the name of the college in the hymn it is preferable to use the abbreviated or acronym naming rather than mentioning its full length.

Language style is a distinctive style or style used by someone to express or express themselves a personal style (Felta, 2020). This method of expression can cover every aspect of language such as diction, use of class language, sentence structure, or forms of discourse. This means that stylistics stems from the form of expression, form of class language, and aspects of sound. For this reason, language is very influential in animating discourse because language is able to present a wealth of meaning, can cause emotive effects for readers or listeners, certain images and atmosphere. The stylistic study in this study emphasizes diction or lexical choice in higher education hymns in Indonesia.

The diction used in higher education hymns in Indonesia is chosen that has the same sound or harmony in the language. This is because college hymns were created to be sung. Therefore, words that have the same sound or harmony at the end of the word with other words will certainly sound more synchronized. The similarity or harmony of the sounds of this language is not only in the words at the end of the line, but also between one word and another in one line. As for the use of language in the hymn song, it can be concluded that the hymn always mentions the name of the college as an interest to show its existence. The purpose of showing this existence is to show the existence of a college to be better known. The form of this existence also shows the conditions or goals to be achieved in education in Indonesia. The picture of Indonesian education is embodied in the hymn, both in direct form in the hymn's lyrics, and in an implied meaning.

Rhetorically, the hymn at state universities in East Java tends to use simple language. This is of course very understandable because the creation of the hymn song is meant to make the hymn easy to understand and easy to remember. However, from the findings of the research, there are quite a lot of use of language styles, especially hyperbole, metaphor, personification, pleonasm, anapora, and symbolics. Of the several language styles found, the use of the personified language style is the most dominant. Personified in the college hymn is the college itself. In this case, tertiary institutions are likened to figures of living beings such as humans who can step, encourage, guide, build, foster, and so on. Apart from personification, other language styles that often appear in hymns of public universities in East Java are hyperbole, metaphorical, pleonasmic, anapora, and symbolic. The use of language style in the college hymn is to create a beautiful impression.

\section{Conclusion}

The following is the complete summary description.

1. The Macro Structure of Higher Education Hymns in Indonesia

The hymns of public universities in East Java have similarities in their macro structure, which is the theme of praise or worship. There are praise or worship aimed at God and also at the institution, some directly at the institution, some are proud of or worship the big names behind the name of the institution, but some have the theme of hope in the institution of pride which becomes determination and enthusiasm.

2. Higher Education Hymn Superstructure in Indonesia

The superstructure or schematic structure of public higher education hymns in East Java begins with a similar naming or title of the hymn, which begins with the word hymn and is followed by the name of the institution. In general, the form of the hymn is made in stanzas like a poem. However, from one college to another, the form of the hymn varies both in the number of stanzas and lines. 
3. The Micro Structure of Higher Education Hymns in Indonesia

The microstructure in this study includes semantic, syntactic, stylistic, and rhetorical elements.

1) Semantics

Semantically, the hymn of state universities in East Java generally directs the audience to an opinion that higher education should be praised and proud of, that the university is qualified and can be trusted. This was stated in the college hymn both explicitly and implicitly. Therefore, for higher education, the presence of hymns can be used as a means of socialization and promotion, to be known to all levels of society throughout the Republic of Indonesia and to be a place of higher education for all young people of all levels of society in Indonesia.

2) Syntax

Syntax studies in discourse analysis include cohesion, coherence, and sentence form. Judging from the cohesion of public higher education hymns in East Java, generally the hymn descriptions are related to the title, both the overall description and the section or section descriptions, even each line in the hymn of public universities in East Java refers to or is directed at the institution whose name is mentioned in the title. . Judging from its coherence, public higher education hymns in East Java generally show descriptions of hymns that are related to one another, both between lines in one stanza and between stanzas. The linkage is there in college hymns it is more about the relationship of meaning. In terms of sentence form, college hymns tend to use long sentences, but they are broken up into lines that seem to appear as sentences. When viewed as sentences, the hymn lines become incomplete sentences, such as sentences without subject, kaliamt not predicate, even sentences without subject and predicate. Another form that appears in higher education hymns in Indonesia is the variation of active and passive voice forms.

3) Stylistics

The stylistics in this study focuses on the diction or lexical choices used in the hymn texts of public universities in East Java. The diction in the text of a college hymn like songs in general is very concerned with the harmony of the sound of the language or emphasizing rhyme and rhyme, especially the diction at the end of the line. The alignment of the sounds in the college hymn is not only in the last word of each line in one stanza but also between the words in one line

4) Rhetoric

The rhetoric study in this study is focused on the use of language styles expressed in the hymn texts of state universities in East Java. The hymns of state universities in East Java tend to use simple language. However, from the analysis results found several language styles. The style of language used in the hymn State universities in East Java are mainly hyperbole, metaphorical, personified, pleonasm, anapora, and symbolic.

\section{References}

Aminuddin. 1987. Pengantar Apresiasi Karya Sastra. Malang: YA3 Malang.

Badara, Aris. 2012. Analisis Wacana: Teori, Metode, dan Penerapannya pada Wacana Media. Jakarta: Kencana Prenanda Media Group.

Basirizadeh, F., et al. (2020). A Study of Wuthering Heights from the Perspective of EcoCriticism. Budapest International Research and Critics in Linguistics and Education (BirLE) Journal Vol 3 (4): 1623-1633.

Darma, Yoce Aliah. 2013. Analisis Wacana Kritis. Bandung: Wrama Widya. 
Darma, Yoce Aliah.2014. Analisis Wacana Kritis dalam Multriprespektif. Bandung: Refika Aditama.

Darwis, M. (2020). Politeness Language Analysis in Teenagers Reviewed from Sociolinguistics. Budapest International Research and Critics in Linguistics and Education (BirLE) Journal Vol I (1): 15-22.

Devy, Shinta Kharisna dan Agus Budi Wahyudi. 2016. Superstruktur wacana fashion dan implementasinya sebagai bahan ajar bahasa Indonesia di sekolah menengah pertama. Tesis Tidak diterbitkan. Universitas Muhammadiyah Surakarta.

Dijk, T.A.Van 2003.Ideology and discourse: A Multidisciplinary Introduction. Barcelona: Pempeu Fabra University.

Eriyanto. 2006. Analisis Wacana: Pengantar Teks Media. Yogyakarta: Lkis.

Brown, Gillian \& Yule, George. 1996. Analisis Wacana (Discourse Analysis). (Terjemahan I. Soetkno). Jakarta: Gramedia Pustaka Utama.

Haryatmoko. 2017. Critical Discourse Analysic. Jakarta: Rajawali Pers.

Jorgensen, M. W dan Phillips, L.J. 2002. Discourse Analysis as Theory and Method.London: Sage Publications Ltd.

Kohn, Hans. 1971. Nasionalisme Arti dan Sejarahnya (terjemahan Sumantri Mertodipura). Pustaka Sardjana, Jakarta.

Kridalaksana, Harimurti.2008. Kamus Linguistik. Jakarta: Gramedia Pustaka

Utama

Liliweri, Alo. 2002. Makna Budaya dalam Komunikasi antar Budaya. Yogyakarta: PT. LKiS Pelangi Aksara. [Serial Online] https:/www.google.co.id/url?sa [10 Januari 2019]

Mills, Sara.1997. Discourse. London: Routledfe.

Santoso, Anang. 2012. Studi Bahasa Kritis, Menguak Bahasa Membongkar Kuasa. Bandung: Mandar Maju

Soedjatmoko, 1991. "Nasionalisme Sebagai Prospek Belajar” dalam majalah Prisma, 2 Februari 1991

Suharyono, dkk. 2014 "Bahasa Dan Ideologi: Mengungkap Ideologi Dan Kekuasaan Simbolik Di Balik Penggunaan Bahasa (Kajian Teks Media Melalui Analisis

Wacana Kritis)”. Dalam Jurnal Humanika Vol. 19 No. 1 (2014) Issn 1412-9418.

Semarang: Fakultas Ilmu Budaya, Universitas Diponegoro.

Undang-undang No.20 Th. 2003 tentang Sistem Pendidikan Nasional.

Harian Surya, 31 Agustus 2016

https//steemit.com/indonesia/@ rial17/perbedaan-himne-dan-mars

https:/vincentcahya.wordpress.com/2015/08/30/mengenal- musik-mars-dan-hymne/ 